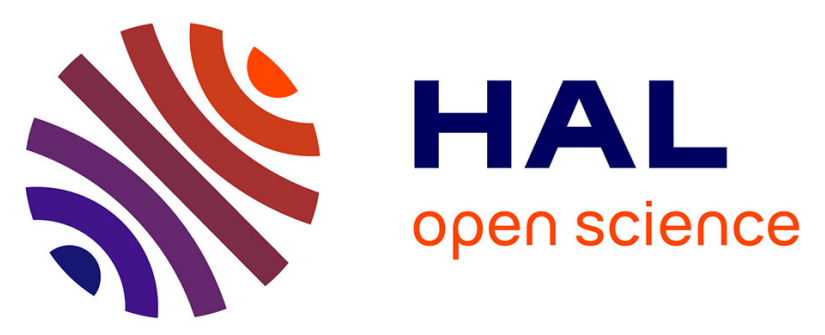

\title{
New insights on mercury abatement and modeling in a full-scale municipal solid waste incineration flue gas treatment unit
}

Lina Maria Romero Millan, Nathalie Lyczko, Ange Nzihou, Gérard Antonini, Eric Moreau, Hubert Richardeau, Christophe Coste, Saïd Madoui, Sylvain Durecu

\section{To cite this version:}

Lina Maria Romero Millan, Nathalie Lyczko, Ange Nzihou, Gérard Antonini, Eric Moreau, et al.. New insights on mercury abatement and modeling in a full-scale municipal solid waste incineration flue gas treatment unit. Waste Management, 2020, 113, pp.270-279. 10.1016/j.wasman.2020.06.003 . hal-02872206

\section{HAL Id: hal-02872206 https://imt-mines-albi.hal.science/hal-02872206}

Submitted on 17 Jun 2020

HAL is a multi-disciplinary open access archive for the deposit and dissemination of scientific research documents, whether they are published or not. The documents may come from teaching and research institutions in France or abroad, or from public or private research centers.
L'archive ouverte pluridisciplinaire HAL, est destinée au dépôt et à la diffusion de documents scientifiques de niveau recherche, publiés ou non, émanant des établissements d'enseignement et de recherche français ou étrangers, des laboratoires publics ou privés. 


\title{
New insights on mercury abatement and modeling in a full-scale municipal solid waste incineration flue gas treatment unit
}

\author{
Lina M. Romero ${ }^{\mathrm{a}, *}$, Nathalie Lyczko ${ }^{\mathrm{a}}$, Ange Nzihou ${ }^{\mathrm{a}}$, Gérard Antonini ${ }^{\mathrm{b}}$, Eric Moreau ${ }^{\mathrm{c}}$, Hubert Richardeau ${ }^{\mathrm{d}}$, \\ Christophe Coste ${ }^{\mathrm{e}}$, Saïd Madoui ${ }^{\mathrm{f}}$, Sylvain Durécu ${ }^{\mathrm{g}}$ \\ a Université de Toulouse, IMT Mines Albi, RAPSODEE CNRS UMR 5302, Campus Jarlard, F.81013 Albi Cedex 09, France \\ ${ }^{\mathrm{b}}$ Association RECORD, Campus LyonTech La Doua, 69603 Villeurbanne cedex, France \\ ${ }^{\mathrm{C}}$ DURAG, 147 Avenue Paul Doumer, 92500 Rueil Malmaison, France \\ d EES-SECAUTO, 2 rue Louis Lépine, BP 40099, 13693 Martigues Cedex, France \\ e Suez RV France, Tour CB21, 16 Place de l'Iris, 92040 Paris-La-Défense, France \\ ${ }^{\mathrm{f}} \mathrm{CME}$ Environnement, 32 rue Edouard Martel, 42000 Saint-Etienne, France \\ ${ }^{\mathrm{g}}$ Séché Environnement, Centre de Recherche, 1425, Avenue Charles de Gaulle, Parc Industriel de la Plaine de l'Ain, 01150 Saint-Vulbas, France
}

Keywords:

Solid waste incineration

Mercury removal efficiency

Mercury transformation mechanisms

Equilibrium and kinetics modelling

Full-scale parametric study

\begin{abstract}
A B S T R A C T
Modeling approaches are generally used to describe mercury transformations in a single step of flue gas treatment processes. However, less attention has been given to the interactions between the different process stages. Accordingly, the mercury removal performance of a full-scale solid waste incineration plant, equipped with a dry flue gas treatment line was investigated using two complementary modeling strategies: a thermochemical equilibrium approach to study the mercury transformation mechanisms and speciation in the flue gas, and a kinetic approach to describe the mercury adsorption process. The modeling observations were then compared to real-operation full-scale data. Considering the typical flue gas composition of waste incineration facilities (high concentrations of $\mathrm{HCl}$ compared to $\mathrm{Hg}$ ), it was found that a process temperature decrease results in better mercury removal efficiencies, associated with a higher oxidation extent of $\mathrm{Hg}$ in $\mathrm{HgCl}_{2}$, and the enhancement of the sorbent capacity. Improvements can also be attained by increasing the sorbent injection rate to the process, or the solid/gas separation cycles. An empirical correlation to predict the mercury removal efficiency from the main operating parameters of dry flue gas treatment units was proposed, representing a useful tool for waste incineration facilities. The presented modeling approach proved to be suitable to evaluate the behavior of full-scale gas treatment units, and properly select the most adequate adjustments in operating parameters, in order to respect the increasingly constraining mercury emissions regulations.
\end{abstract}

\section{Introduction}

Incineration is a widely used treatment method for waste materials that allow the reduction of their volume and hazard. It is generally used for municipal solid wastes (MSW), sewage sludge, and hospital residues (Beylot et al., 2018). However, even if this process in an interesting solution for waste management, the associated gaseous emissions may pose several risks to human health, wildlife, and ecosystems, if not treated, as they contain large amounts of pollutants such as acid gases $\left(\mathrm{HCl}, \mathrm{SO}_{2}, \mathrm{HF}\right)$, heavy metals $(\mathrm{Hg}$, $\mathrm{Cd}, \mathrm{As}, \mathrm{Ni}, \mathrm{Pb}$, etc), NOx, dioxins, and furans (Ahmad et al., 2018; Quina et al., 2008). In particular, mercury is one of the most hazardous metals in municipal and hospital incineration flue gases

\footnotetext{
* Corresponding author.

E-mail address: lina.romero_millan@mines-albi.fr (L.M. Romero).
}

due to its high volatility, persistence, long-distance migration, and bioaccumulation (Ha et al., 2017; Tao et al., 2017).

In consequence, rigorous regulations regarding mercury emissions from waste incineration facilities are applied in most developed countries. As far as the European Union (EU) is concerned, the industrial emissions directive 2010/75/UE sets the maximum pollutant levels to be respected by the EU member states, in the Best Available Techniques REFerence document for Waste Incineration - WI BREF. In particular, a new revision of this document, stablishes that the daily average mercury emissions to air of waste incineration facilities must be below $5-20 \mu \mathrm{g} / \mathrm{Nm}^{3}$, depending on the used gas treatment technologies and mercury content in the input waste stream (European Commission, 2019). From the acceptance of this revision in November 2019, the EU member states will have 4 years to implement the required technical measures and adopt the new threshold values. 
To effectively respect these regulations, several existing incineration plants will be constrained to adapt their flue gas treatment process, giving particular attention to mercury removal strategies. For this purpose, it is important to fully understand the mercury transformation mechanisms during the gas treatment process, and the impact of the operating parameters on mercury removal efficiency.

In this regard, process simulation is an interesting approach to analyze the effect of different operating conditions on mercury speciation and removal, through the different compartments of a flue gas treatment line. In the presented context, the application of this approach to industrial-scale units could be particularly useful, as it allows the identification of the most suitable adjustments to be performed in waste incineration plants, in order to reduce mercury emissions, before doing any modification in the plant layout or operation (Jannelli and Minutillo, 2006). Modeling approaches have been generally used to describe the mercury transformations in a single step of the flue gas treatment process (Antonioni et al., 2014; Gharebaghi et al., 2011; Xu et al., 2003). However, less attention has been given to the possible interactions between the different sections of a gas treatment line, and the impact of the process operating conditions and reactants on the global mercury removal efficiency.

In accordance, the aim of this work is to understand the mercury transformation mechanisms taking place in the different sections of an industrial flue gas treatment line, and to identify the operating parameters and interactions that have the greatest impact on mercury adsorption and removal efficiency. For this purpose, a solid waste incineration plant, equipped with a dry flue gas treatment line was analyzed using two complementary modeling strategies. A thermochemical equilibrium approach to study the mercury transformations and speciation in the flue gases, and a kinetic approach to describe the mercury adsorption process on activated lignite. The modeling observations were compared to the results of a full-scale parametric study, performed in the analyzed flue gas treatment line. Accordingly, the validity of the proposed simulation approach was discussed, and the key parameters associated to the reduction of mercury emissions were identified.

\section{Materials and methods}

\subsection{Description of the flue gas treatment unit considered}

A solid waste incineration plant located in France was considered in the present study. The unit is able to treat around
150,000 tons of wastes per year (including urban, commercial, and hospital residues), recovering the available energy to produce heat and power. The facility consists in two incineration lines equipped with dry flue gas treatment units. Accordingly, the present study is based on the modeling and process analysis of the gas treatment unit of one incineration line, with a nominal waste feed rate of 9.5 tons/h.

The flue gas treatment purpose is the removal of the typical gaseous pollutants produced during the incineration of wastes: acid gases $\left(\mathrm{HCl}, \mathrm{SO}_{2}\right)$, heavy metals (mainly $\mathrm{Hg}$ ), dioxins, furans, and nitrogen oxides. In this case, a dry cleaning process is used, including three main stages. The first one corresponds to a spray tower to reduce the temperature of the flue gas to temperatures between $210{ }^{\circ} \mathrm{C}$ and $180^{\circ} \mathrm{C}$. Then, sodium bicarbonate $\left(\mathrm{NaHCO}_{3}\right)$ and activated lignite are injected to the process line (in-duct) to neutralize acid gases and capture heavy metals, dioxins, and furans, followed by a pulse-jet fabric filter. Finally, after the solid removal from the gas stream, the flue gas treatment is completed by a selective catalytic reduction unit (SCR), where an ammonia solution is fed into a catalytic reactor to reduce nitrogen oxides emissions. The general plant layout of the flue gas treatment unit analyzed in this study is schematized in Fig. 1.

The flue gas composition is continuously measured at three significant points of the treatment line, in order to monitor the performance of the different stages. The first point is located at the inlet of the spray tower (ST), the second one at the exit of the bag filter $(\mathrm{EF})$, and the last one at the chimney exit $(\mathrm{CH})$. The $\mathrm{HCl}, \mathrm{SO}_{2}, \mathrm{O}_{2}$, and $\mathrm{H}_{2} \mathrm{O}$ concentration measurement is performed online using FTIR analyzers, provided by Secauto, and the mercury concentration and speciation ( $\mathrm{Hg}$ tot, $\mathrm{Hg}^{\circ}$ and $\mathrm{Hg}^{\mathrm{n}+}$ ) using Durag $\mathrm{HM}-$ 1400-TRX2 total mercury analyzers. The flue gas temperature is also continuously measured at the three described points, as well as the dust content in the gas at the chimney exit. The daily average operating parameters and flue gas composition of the analyzed gas treatment unit, considered for this study, are presented in Table 1, for the three described stages and measurement points.

\subsection{Modeling of the described flue gas treatment}

Given the steps described above, the modeling of the flue gas treatment process has been also divided in three main sections: flue gas cooling tower, acid gases and mercury removal stage, and selective catalytic reduction unit. The analysis of the process has been performed using two complementary strategies. In a first stage, a thermochemical equilibrium approach allowed the analysis of mercury speciation in the different compartments of the gas

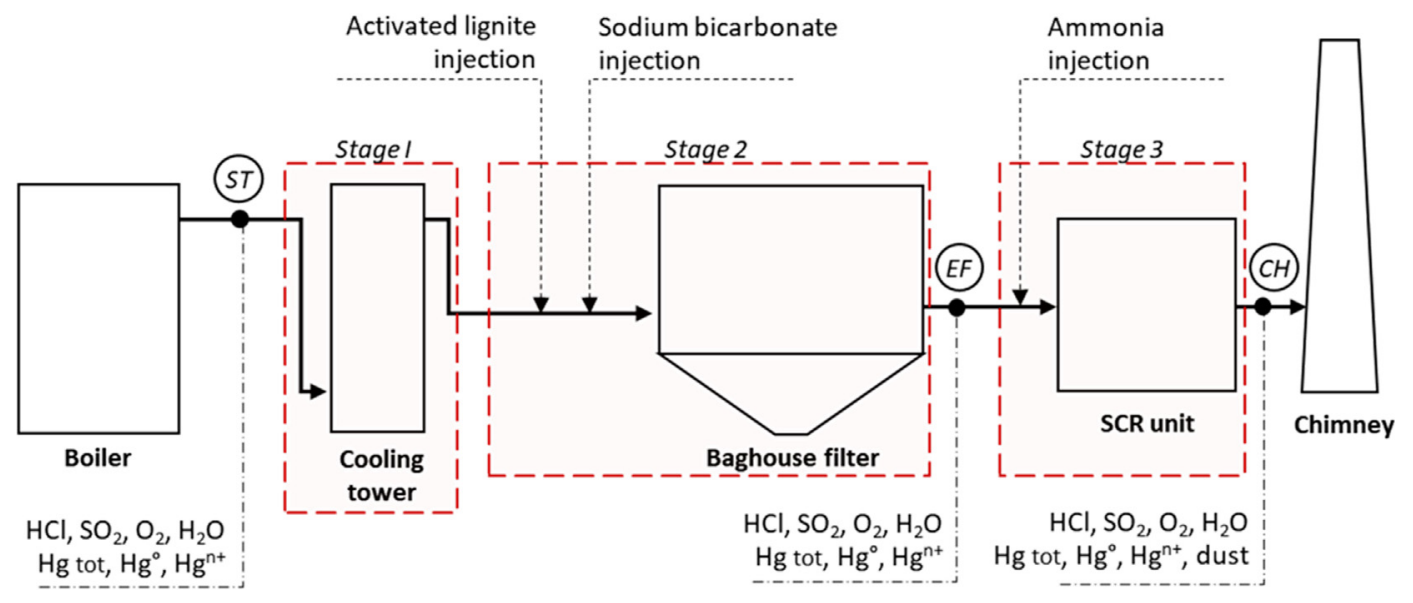

Fig. 1. Overall MSW flue gas treatment unit layout and analyzed sections. 
Table 1

Average flue gas composition at the three measurement points and operating parameters.

\begin{tabular}{|c|c|c|c|}
\hline \multicolumn{4}{|l|}{ Flue gas composition } \\
\hline & Spray tower inlet (ST) & Fabric filter exit (EF) & Chimney exit $(\mathrm{CH})$ \\
\hline NO (mg/Nm³ dry gas) & $280.2 \pm 21.5$ & $290.7 \pm 36.0$ & $58.1 \pm 10.8$ \\
\hline $\mathrm{HCl}\left(\mathrm{mg} / \mathrm{Nm}^{3}\right.$ dry gas $)$ & $785.0 \pm 78.0$ & $5.7 \pm 1.6$ & $5.5 \pm 3.3$ \\
\hline $\mathrm{SO}_{2}\left(\mathrm{mg} / \mathrm{Nm}^{3}\right.$ dry gas $)$ & $32.3 \pm 8.0$ & $6.0 \pm 1.8$ & $4.7 \pm 2.5$ \\
\hline $\mathrm{O}_{2}$ (vol\% dry gas) & $8.6 \pm 0.5$ & $9.0 \pm 0.5$ & $9.3 \pm 1.0$ \\
\hline $\mathrm{H}_{2} \mathrm{O}\left(\mathrm{vol}_{\%}\right)$ & $18.4 \pm 0.5$ & $19.4 \pm 1.8$ & $19.2 \pm 1.7$ \\
\hline $\mathrm{Hg}$ tot $\left(\mu \mathrm{g} / \mathrm{Nm}^{3}\right.$ dry gas $)$ & $98.0 \pm 50.2$ & $10.5 \pm 6.2$ & $11.0 \pm 6.5$ \\
\hline $\mathrm{Hg}^{\mathrm{n}+}\left(\mu \mathrm{g} / \mathrm{Nm}^{3}\right.$ dry gas $)$ & $90.5 \pm 48.7$ & $9.9 \pm 5.4$ & $10.3 \pm 5.6$ \\
\hline Dust $\left(\mathrm{mg} / \mathrm{Nm}^{3}\right.$ dry gas) ${ }^{\mathrm{a}}$ & - & - & $0.2 \pm 0.1$ \\
\hline \multicolumn{4}{|l|}{ Average operating parameters } \\
\hline \multirow[t]{3}{*}{ Spray cooling tower } & Inlet flow rate $\left(\mathrm{Nm}^{3} / \mathrm{h}\right)$ & & 55,000 \\
\hline & Inlet flue gas temperature $\left({ }^{\circ} \mathrm{C}\right)$ & & 300 \\
\hline & Outlet flue gas temperature $\left({ }^{\circ} \mathrm{C}\right)$ & & 195 \\
\hline \multirow[t]{5}{*}{ Pulse-jet fabric filter } & Inlet flue gas temperature $\left({ }^{\circ} \mathrm{C}\right)$ & & 195 \\
\hline & Outlet flue gas temperature $\left({ }^{\circ} \mathrm{C}\right)$ & & 185 \\
\hline & $\mathrm{NaHCO}_{3}$ feed rate $(\mathrm{kg} / \mathrm{h})$ & & 80 \\
\hline & Average filtration cycle time (s) & & 600 \\
\hline & Activated lignite feed rate $(\mathrm{kg} / \mathrm{h})$ & & 5 \\
\hline \multirow[t]{3}{*}{ Selective catalytic reduction unit } & Inlet temperature $\left({ }^{\circ} \mathrm{C}\right)$ & & 185 \\
\hline & Outlet temperature $\left({ }^{\circ} \mathrm{C}\right)$ & & 183 \\
\hline & $\mathrm{NH}_{3}$ feed rate $(1 / \mathrm{h})$ & & 15.3 \\
\hline
\end{tabular}

\footnotetext{
a The dust content in the flue gas was only measured at the chimney exit $(\mathrm{CH})$.
}

treatment line. Afterwards, considering that the mercury capture by activated lignite cannot be described by a thermodynamics analysis, a kinetic approach was used to model the adsorption phenomena.

\subsubsection{Thermochemical equilibrium modeling of mercury speciation}

The thermochemical equilibrium approach allows the analysis of the feasibility or spontaneity of chemical transformations from the knowledge of the global parameters of the process, i.e. composition, pressure and temperature (Zhou et al., 2013). Nevertheless, some limitations must be considered when applying this strategy to flue gas treatment analysis. In particular, equilibrium calculations involve a homogeneous and closed-system assumption, and do not account for concentration or temperature gradients. Moreover, they do not allow the description of physical processes in the flue gas, such as mercury adsorption by solid reactants or gas-solid interactions with fly-ashes (Abanades et al., 2002). Only the homogeneous reactions between gas-phase reactants can be considered.

Despite these limitations and the fact that the considered flue gas treatment stages do not reach the thermodynamic equilibrium state due to their complex operating conditions, the thermochemical equilibrium assumption is generally adequate to analyze the fate of most gaseous species produced during combustion process. In particular, different authors have proved that thermodynamic equilibrium approach gives reasonable results for mercury transformations during coal-combustion flue gas treatment (Hall et al., 1991, 1990; Zhou et al., 2013), being also considered as a suitable strategy for the analysis of MSW incineration flue gas (Abanades et al., 2002; Jannelli and Minutillo, 2006).

In this regard, the thermochemical equilibrium condition of each section is evaluated by minimizing the Gibbs free energy of the system $(\Delta G)$ (Nichita et al., 2002; Shabbar and Janajreh, 2012). To perform these calculations, the equilib module of the software FactSage ${ }^{\circledR}$ was used, considering the average flue gas composition and process conditions at the inlet of each stage. Thermochemical information of elements and compounds was taken from the SGPS and ELEM databases included in FactSage ${ }^{\circledR}$ software (Bale et al., 2016).

2.2.1.1. Flue gas cooling stage. As the main objective of the spray tower is the cooling of the incineration flue gases, the thermochemical equilibrium approach was employed to analyze the impact of temperature on the mercury speciation in the gas. Moreover, to better understand the transformations and oxidation mechanisms taking place during the cooling process, the effect of the flue gas composition was also investigated. Since $\mathrm{O}_{2}, \mathrm{HCl}, \mathrm{SO}_{2}$ and $\mathrm{NO}$ are the main mercury oxidation agents in the flue gases, the impact of each individual compound was studied, as well as their possible interactions.

2.2.1.2. Acid gases and mercury removal stage. The second section of the flue gas treatment line analyzed in this work includes the removal of acid gases $\left(\mathrm{HCl}, \mathrm{SO}_{2}\right)$, heavy metals (mainly $\mathrm{Hg}$ ), and dioxins and furans from the exhaust stream. For this purpose, $\mathrm{NaHCO}_{3}$ and powdered activated lignite are directly injected in the flue gas pipe (in-duct treatment), followed by a solid/gas separation step in a bag filter. In particular, $\mathrm{NaHCO}_{3}$ is related to acid gas removal, while activated lignite is associated to mercury abatement (Dal Pozzo et al., 2019; Pavlish et al., 2003; Srivastava et al., 2001). Considering that the injection of solid reactants is done simultaneously, the analysis of mercury transformations and mercury removal in this section was performed in two steps. At first, the influence of $\mathrm{NaHCO}_{3}$ on mercury speciation in the flue gas was analyzed using a thermochemical equilibrium approach. Then, since this approach does not allow the description of physical processes in the flue gas, the mechanisms related to mercury adsorption by activated lignite were studied in detail considering the process kinetics, as described in Section 2.2.2. It is worth mentioning that as reported by different authors, the fly-ashes may also contribute to the mercury removal from flue gases, via heterogeneous oxidation and/or adsorption processes, depending on their unburned carbon content and mineral composition (Feeley et al., 2009; Hassett and Eylands, 1999; Rumayor et al., 2018). However, since their mercury capture capacity is considerably low in comparison to activated lignite (Karatza et al., 1998; Lighty et al., 2008), the impact of fly-ashes on mercury removal is not considered in this study.

2.2.1.3. Selective catalytic reduction unit (SCR) - NOx removal system. The last stage of the analyzed flue gas treatment line is dedicated to NOx removal using a selective catalytic reduction unit (SCR). For this purpose, $\mathrm{NH}_{3}$ is injected into the exhaust stream in the presence of a catalyzer, promoting the destruction of nitrogen oxides by their transformation in $\mathrm{N}_{2}$ and $\mathrm{H}_{2} \mathrm{O}$ (Cheng and $\mathrm{Bi}, 2014$ ). 
Even though the capture of mercury compounds was mainly performed by the injection of activated lignite in the previous stage of the process, a small fraction of pollutants may still remain in the exhaust stream.

In this regard, in the presented facility layout, the SCR unit is not directly related to mercury removal. However, it is well known that selective catalytic units may also oxidize elemental mercury in the flue gases (Eswaran and Stenger, 2005). In accordance, the thermochemical equilibrium analysis of this process step may help to understand the mercury speciation behavior through the SCR unit and the impact of $\mathrm{NH}_{3}$ injection. In this point it is important to clarify that as previously stated, the equilibrium analysis does not allow the study of the heterogeneous reactions between the flue gases and the catalyzer surface. Only the homogeneous reactions between gas-phase reactants are considered in this work.

\subsubsection{Mercury adsorption modeling on activated lignite}

The mercury adsorption process in the second stage of the analyzed flue gas treatment unit was modeled using Aspen Adsorption $^{\mathrm{TM}}$ V8.4. In the presented plant layout, mercury adsorption takes place predominately in the fabric filter, considering the short residence time of the reactants in the feeding duct (Scala, 2001a; Wang et al., 2008). Accordingly, the model is focused on the description of the fabric filter.

Unlike the thermodynamic equilibrium analysis, the modeling of mercury adsorption should also take into account the gas flow and composition through the process, the physico-chemical characteristics of the adsorbent material, and the bag filter operating parameters, as well as a simplified geometry of the filtration surface. In particular, the impact of different operating parameters on the mercury removal efficiency was studied. Thus, the activated lignite flow rate, the temperature through the baghouse, and the filtration cycle time were the analyzed parameters. In this regard, a fixed-bed adsorption unit of equivalent surface area to the analyzed fabric filter was considered. The physico-chemical properties of the activated lignite, and the characteristics of the modelled adsorbent bed are summarized in Table 2. Taking into account that the amount of lignite coke and sodium bicarbonate accumulated in the bag filter varies with time, the thickness of the filter cake was determined for a specific filtration cycle time, from the average mass flow of solid reactants, according to Eq. (1) (Chen and Hsiau, 2009):

$$
\boldsymbol{L}(\boldsymbol{t})=\frac{\dot{m} \boldsymbol{t}}{A \rho_{p}(1-\varepsilon)}
$$

With $L$ the thickness of the filter cake $(\mathrm{cm})$, m the mass flow rate of activated lignite and $\mathrm{NaHCO}_{3}(\mathrm{~g} / \mathrm{s}), t$ the filtration cycle time (s), $A$ the filtration area $\left(\mathrm{cm}^{2}\right), \rho_{p}$ the solid particles density $\left(\mathrm{g} / \mathrm{cm}^{3}\right)$, and $\varepsilon$ the filtration bed porosity (-). It is assumed that the activated lignite and sodium bicarbonate particles are spherical and uniformly dispersed over the entire filtration surface. Additionally, the gas flow and the reactant injection to the process is considered constant during the filtration cycle. As previously stated, the contribution of the fly-ashes to the mercury removal is not considered in this stage.

To take into consideration the mass transfer resistances present in the gas phase adsorption process (e.g. mass transfer resistance between the bulk gas phase and the solid interface, and intraparticle transport mechanism through the adsorbent pore structure) (Garrick and Bühlmann, 2018), the particle MB2 model in Aspen Adsorption ${ }^{\mathrm{TM}}$ was used. This model assumes that the activated lignite particles have a uniform pore structure and that the effective gas-phase diffusion coefficient is constant. The latter one is calculated from the values of the mercury diffusion coefficient in air, reported in the literature, and the Knudson diffusion
Table 2

Activated lignite and adsorbent bed characteristics.

\begin{tabular}{|c|c|c|}
\hline \multicolumn{3}{|c|}{ Adsorbent characteristics - Activated lignite $\mathrm{HOK}^{\circledR}$} \\
\hline \multicolumn{2}{|c|}{ Particle size $d_{50}(\mu \mathrm{m})$} & 63 \\
\hline \multicolumn{2}{|c|}{$\mathrm{S}_{\mathrm{BET}}\left(\mathrm{m}^{2} / \mathrm{g}\right)$} & 300 \\
\hline \multicolumn{2}{|c|}{ Average pore diameter $(\mu \mathrm{m})$} & 1 \\
\hline \multicolumn{2}{|c|}{ Particle porosity (-) } & 0.5 \\
\hline \multicolumn{2}{|c|}{ Particle density $\left(\mathrm{kg} / \mathrm{m}^{3}\right)^{\mathrm{a}}$} & 700 \\
\hline \multicolumn{3}{|c|}{ Elemental analysis } \\
\hline \multicolumn{2}{|c|}{ C (wt\% db.) } & 87.9 \\
\hline \multicolumn{2}{|c|}{$\mathrm{H}(\mathrm{wt} \% \mathrm{db})}$. & 0.4 \\
\hline \multicolumn{2}{|c|}{$\mathrm{O}(\mathrm{wt} \% \mathrm{db})}$. & 0.6 \\
\hline \multicolumn{2}{|c|}{$\mathrm{N}(\mathrm{wt} \% \mathrm{db})}$. & 0.5 \\
\hline \multicolumn{2}{|c|}{ S (wt\% db.) } & 0.6 \\
\hline \multicolumn{2}{|c|}{ Ash (wt\% db.) } & 10.0 \\
\hline \multicolumn{3}{|c|}{ Adsorbent bed characteristics } \\
\hline \multicolumn{2}{|c|}{ Filtration area $\left(\mathrm{m}^{2}\right)$} & 2290 \\
\hline \multicolumn{2}{|c|}{ Bed porosity $(-)$} & 0.5 \\
\hline \multicolumn{2}{|c|}{ Air-to-cloth ratio $(\mathrm{m} / \mathrm{s})$} & 0.007 \\
\hline \multicolumn{3}{|c|}{ Langmuir parameters considered for simulation ${ }^{\mathrm{b}}$} \\
\hline \multicolumn{2}{|c|}{$K_{0}\left(\mathrm{~m}^{3} / \mathrm{g}\right)$} & 0.37 \\
\hline \multicolumn{2}{|c|}{$\Delta H_{a d s}(\mathrm{~kJ} / \mathrm{mol})$} & -22 \\
\hline \multirow[t]{2}{*}{$200{ }^{\circ} \mathrm{C}$} & $K\left(\mathrm{~m}^{3} / \mathrm{g}\right)$ & 100 \\
\hline & $\omega_{\max }(-)$ & 0.055 \\
\hline \multirow[t]{2}{*}{$150{ }^{\circ} \mathrm{C}$} & $K\left(\mathrm{~m}^{3} / \mathrm{g}\right)$ & 205 \\
\hline & $\omega_{\max }(-)$ & 0.160 \\
\hline \multirow[t]{2}{*}{$120^{\circ} \mathrm{C}$} & $K\left(\mathrm{~m}^{3} / \mathrm{g}\right)$ & 312 \\
\hline & $\omega_{\max }(-)$ & 0.171 \\
\hline
\end{tabular}

\footnotetext{
a From (Ruthven, 1984).

b From (Karatza et al., 1996b). $\mathrm{HgCl}_{2}$ adsorption on activated carbon impregnated with $18.7 \% \mathrm{Na}_{2} \mathrm{~S}$.
}

coefficient (Skodras et al., 2008; Zhou et al., 2015). For its part, the boundary layer mass transfer coefficient was determined using the Sherwood number correlation (Skodras et al., 2008). The pressure and gas velocity inside the bed are related by the Ergun equation. Moreover, the temperature is considered constant through the filter, and the mercury adsorption heat effects are neglected due to the low concentration of mercury in the flue gases.

The Langmuir theory was used to describe the adsorption equilibrium of mercury on activated lignite. Since no experimental isotherm parameters are reported in the literature for this specific adsorbent/adsorbate couple (e.g. asymptotic adsorbate concentration $\omega_{\max }$, and equilibrium constant $K$ ), the corresponding values for mercury adsorption on sulfur impregnated activated carbon with similar surface area, proposed by Karatza et al. are considered in this work (Karatza et al., 1996b, 1996a). Moreover, it is assumed that in the operating temperature range of the fabric filter, the temperature dependence of the equilibrium constant $K$ can be described by an Arrhenius type equation, with $K_{0}$ and $\Delta H_{a d s}$ the preexponential factor and the heat of adsorption, respectively. These parameters, also proposed by Karatza el al. are summarized in Table 2.

In accordance, the mercury concentration in the flue gas at the exit of the fabric filter can be determined by the process simulation. Thus, the mercury removal efficiency (MRE) during a filtration cycle is calculated from the following equation:

$\operatorname{MRE}(\%)=\frac{C_{\text {Hginlet }}-C_{\text {Hgoutlet }}}{C_{\text {Hginlet }}} \cdot 100$

where $C_{H g}$ inlet and $C_{H g}$ outlet are the mercury concentrations at the inlet and at the outlet of the fabric filter.

\subsection{Comparison between simulation and full-scale parametric analysis results}

In addition to the process simulation, a parametric study was performed in the described flue gas treatment unit to validate the impact of the operating parameters on the global mercury 
removal efficiency of the installation. In particular, the gas temperature at the outlet of the gas cooling tower, the activated lignite injection rate, and the filtration cycle time through the bag filter were the parameters considered. The adjustments of the process parameters were performed independently, and their impact was evaluated during an observation period of 2 months to take account of the variability of the flue gas conditions, as summarized in Table 3.

It is worth noting that the filtration cycle time is also controlled in industrial facilities by the pressure drop through the filter. In fact, the filter cleaning is triggered when the filtration time set point or the pressure drop set point are exceeded, whichever occurs first. In accordance, both values are presented in Table 3. Even though the filtration cycle time is inevitably influenced by other operation parameters like the solid sorbents injection rate, the analysis of the pressure drop values continuously measured through the filter during the parametric tests, suggests that the average interval between two cleaning stages is close to the filtration cycle time set point, and then, this value can be considered as a reasonable average for the filter operation.

For the performed parametric tests, the global mercury removal efficiency was calculated according to Eq. (2), considering the total mercury concentration measured at the inlet of the cooling tower (ST) and the chimney exit $(\mathrm{CH})$. To assess the impact of the analyzed parameters, the mercury removal efficiency of the flue gas treatment unit was calculated as a monthly average, considering the observation period of the test runs. Then, the comparison between the simulation and the full-scale parametric analysis results was performed. For all the tested operating conditions, the calculated standard deviation of the monthly mercury removal efficiency was below 3\%, suggesting that the results of the performed parametric analysis are statistically significant and show the impact of the main process parameters on the flue gas treatment unit performance.

\section{Results and discussion}

\subsection{Flue gas cooling stage modeling}

\subsubsection{Impact of flue gas temperature on mercury speciation}

For the analyzed plant layout, and considering the flue gas composition at the inlet of the cooling tower, summarized in Table 1 , the thermochemical equilibrium calculations showed that the process temperature in this stage has an important impact on the mercury speciation in the gas. In particular, in the temperature range between $150{ }^{\circ} \mathrm{C}$ and $800{ }^{\circ} \mathrm{C}$, the temperature decrease enhances the mercury oxidation to $\mathrm{HgO}$ and $\mathrm{HgCl}_{2}$, as presented in Fig. 2 .

At $800{ }^{\circ} \mathrm{C}$ only a small fraction of mercury is present in the flue gases as $\mathrm{HgO}$, and predominantly exists in its elementary form $\mathrm{Hg}^{\circ}$. In contrast, gas cooling below $700{ }^{\circ} \mathrm{C}$ results in a fast transformation of elemental mercury in $\mathrm{HgCl}_{2}$. Clearly, $\mathrm{HgCl}_{2}$ is the main mercury compound formed during the flue gas cooling process under the analyzed conditions ( $>99 \%$ ). This behavior is in agreement with various reported results, considering that $\mathrm{HCl}$ is a significant component of MSW incineration flue gas, and chlorine has been identified as the main gas phase reactant influencing mercury oxidation (Hall et al., 1991; Xu et al., 2003).

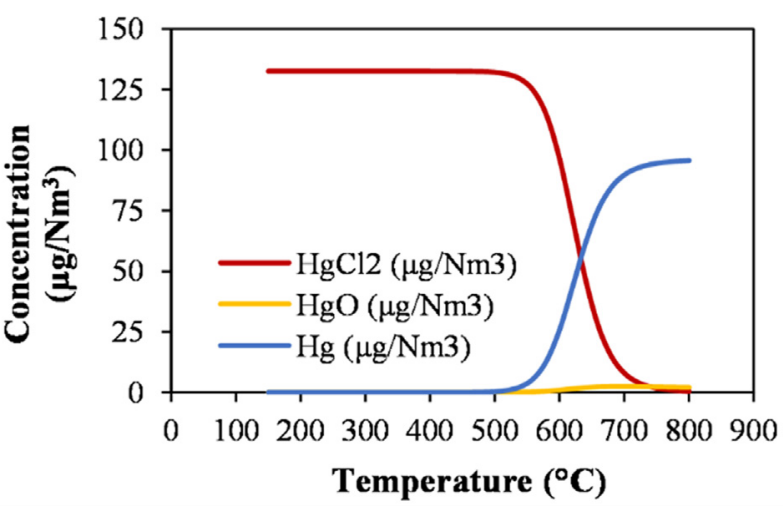

Fig. 2. Effect of temperature on mercury speciation transformations. Flue gas composition at the inlet of the cooling tower as described in Table 1.

In accordance, temperature reduction is a very important step in the flue gas treatment process, since the removal of oxidized mercury compounds $\left(\mathrm{Hg}^{\mathrm{n}+}\right)$ can be performed more efficiently, in comparison to elemental mercury $\left(\mathrm{Hg}^{\circ}\right)$ (Carey et al., 1998; Ie et al., 2013; Pavlish et al., 2003; Rumayor et al., 2018). Therefore, the increase of the ratio $\mathrm{Hg}^{\mathrm{n}+} / \mathrm{Hg}^{\circ}$ in the flue gases will be related to a better mercury removal efficiency in the following steps of the treatment process.

\subsubsection{Impact of flue gas composition on mercury speciation}

The impact of the flue gas composition on the mercury speciation was analyzed in detail at the average outlet temperature of the studied cooling tower $\left(195{ }^{\circ} \mathrm{C}\right)$. As already stated, $\mathrm{O}_{2}, \mathrm{HCl}, \mathrm{SO}_{2}$ and NO are the main mercury oxidizing agents present in solid waste incineration flue gases. In accordance, the influence of each compound was analyzed separately in a first stage, and then, the possible interactions between them were also evaluated.

\section{- Influence of oxygen concentration}

Considering the oxygen concentration in the flue gas $(\sim 9 \%)$, it was observed from the thermochemical equilibrium study that oxygen promotes mercury transformation in $\mathrm{HgO}$, in the absence of other oxidizing agents, through the following homogeneous reaction:

$\mathrm{Hg}_{(g)}^{0}+1 / 2 \mathrm{O}_{2(g)} \rightarrow \mathrm{HgO}_{(g)}$

Accordingly, the simulation results presented in Fig. 3a show that the transformation of mercury in $\mathrm{HgO}$ takes place in some extent in the presence of $\mathrm{O}_{2}$. However, even with relatively high oxygen concentrations in the flue gas $(>8 \%)$, elemental mercury is the dominant species leaving the cooling tower.

These results are in accordance with different authors that analyzed the mercury transformation reactions in simulated incineration flue gases with similar compositions $\left(\mathrm{Hg}+\mathrm{O}_{2}+\mathrm{N}_{2}\right)$, and suggest that oxygen is a weak promoter of homogeneous mercury oxidation in the absence of other oxidizing agents (Niksa et al., 2001). In contrast, the equilibrium analysis showed that oxygen is a key factor in mercury oxidation in the presence of other gases like $\mathrm{HCl}$ and $\mathrm{SO}_{2}$, as detailed below.

Table 3

Parameter adjustments performed in the full-scale flue gas treatment unit.

\begin{tabular}{|c|c|c|c|}
\hline & Parameter adjustments & & Observation period \\
\hline Spray cooling tower & Outlet temperature & $205^{\circ} \mathrm{C} \rightarrow 195^{\circ} \mathrm{C}$ & 2 months \\
\hline \multirow[t]{2}{*}{ Pulse-jet fabric filter } & Activated lignite feed rate & $5 \mathrm{~kg} / \mathrm{h} \rightarrow 10 \mathrm{~kg} / \mathrm{h}$ & 2 months \\
\hline & Filtration cycle time & $600 \mathrm{~s}(12 \mathrm{mbar}) \rightarrow 900 \mathrm{~s}(14 \mathrm{mbar})$ & 2 months \\
\hline
\end{tabular}



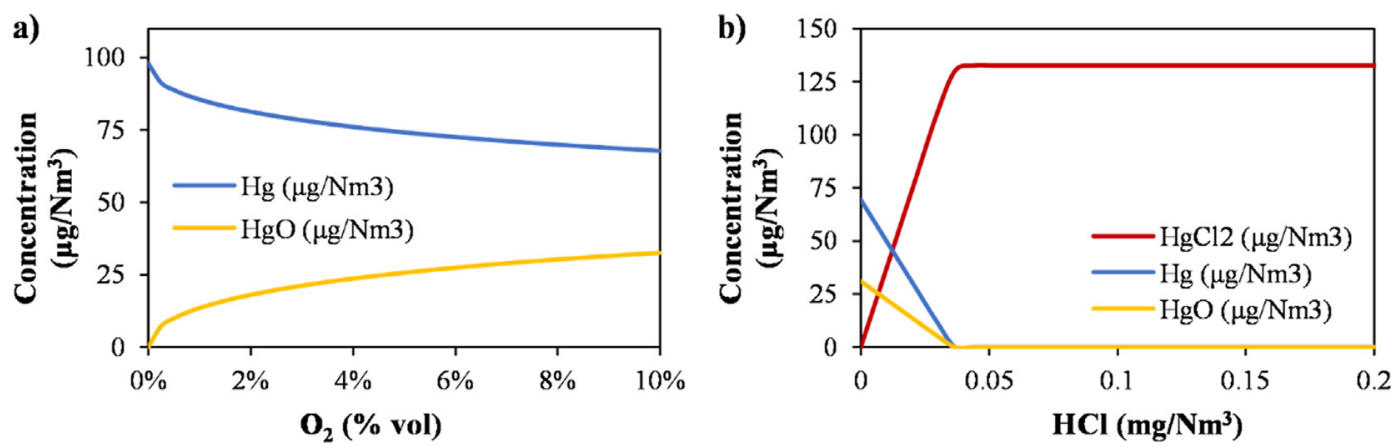

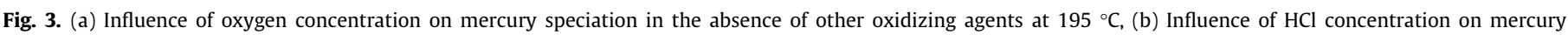
speciation. $195{ }^{\circ} \mathrm{C}, 8.6 \mathrm{vol} \%$ sec $\mathrm{O}_{2}$.

\section{- Influence of $\mathrm{HCl}$ concentration}

The equilibrium calculations showed that in the absence of other oxidizing agents, the reaction between $\mathrm{Hg}$ and $\mathrm{HCl}$ is not predominant and elemental mercury is the main species observed in the flue gases. These results, in agreement with different authors, showed that elementary reactions between $\mathrm{Hg}$ and $\mathrm{HCl}$ in inert gas have a very high energy barrier, and does not occur at the typical cooling tower temperatures in solid waste incineration plants (e.g. $180-300{ }^{\circ} \mathrm{C}$ ) (Hranisavljevic and Fontijn, 1997a; Sliger et al., 2000).

In contrast, it was observed that mercury oxidation by $\mathrm{HCl}$ is favored by oxygen, being mercury chloride $\left(\mathrm{HgCl}_{2}\right)$ the dominant compound formed. In this regard, considering the oxygen content in the analyzed incineration plant, the simulation results show that mercury oxidation increases with $\mathrm{HCl}$ concentration, as presented in Fig. $3 \mathrm{~b} . \mathrm{Hg}^{\circ}$ and $\mathrm{HgO}$ are the main mercury species in the absence of $\mathrm{HCl}$. Then, the $\mathrm{HgCl}_{2}$ concentration increases with $\mathrm{HCl}$, reaching a maximum when a molar ratio $\mathrm{HCl} / \mathrm{Hg}$ of 2 is attained. Above this ratio, almost all the mercury in the flue gases is present as $\mathrm{HgCl}_{2}$ at equilibrium conditions (>99\%). This behavior suggests the following reaction mechanism, postulated by Hall et al (Hall et al., 1990), with $\mathrm{HgO}$ acting as an intermediate in the formation of $\mathrm{HgCl}_{2}$.

$\mathrm{Hg}_{(g)}^{0}+2 \mathrm{HCl}_{(g)}+1 / 2 \mathrm{O}_{2(g)} \rightarrow \mathrm{HgCl}_{2(g)}+\mathrm{H}_{2} \mathrm{O}_{(g)}$

$\mathrm{Hg}_{(g)}^{0}+1 / 2 \mathrm{O}_{2(g)} \rightarrow \mathrm{HgO}_{(g)}$

$\mathrm{HgO}_{(g)}+2 \mathrm{HCl}_{(g)} \rightarrow \mathrm{HgCl}_{2(g)}+\mathrm{H}_{2} \mathrm{O}_{(g)}$

Several authors have indicated that mercury oxidation may also occur via chlorine intermediates like atomic chlorine or $\mathrm{Cl}_{2}$. However, it has been demonstrated that the conversion of $\mathrm{HCl}$ to $\mathrm{Cl}_{2}$ in the flue gas conditions is kinetically limited (Hranisavljevic and Fontijn, 1997b; Senior et al., 2000; Xu et al., 2003), and accordingly, the presented mechanism may be the most suitable to explain the homogenous mercury oxidation by $\mathrm{HCl}$ in the analyzed plant conditions.

\section{- Influence of $\mathrm{SO}_{2}$ concentration}

As in the case of $\mathrm{HCl}$, the thermochemical equilibrium calculations showed that no reactions occur between $\mathrm{SO}_{2}$ and $\mathrm{Hg}^{\circ}$ in inert atmosphere. In contrast, in the presence of oxygen, $\mathrm{HgSO}_{4}$ (s) may be the main mercury compound formed during the gas cooling process. In this case, $\mathrm{HgO}$ may also be considered as an intermediate in the formation of $\mathrm{HgSO}_{4}(\mathrm{~s})$, probably following the reaction mechanism presented below:
$\mathrm{Hg}_{(g)}^{0}+1 / 2 \mathrm{O}_{2(g)} \rightarrow \mathrm{HgO}_{(g)}$

$\mathrm{HgO}_{(g)}+\mathrm{SO}_{2(g)}+1 / 2 \mathrm{O}_{2(g)} \rightarrow \mathrm{HgSO}_{4(s)}$

Some authors have also suggested that $\mathrm{SO}_{2}$ may have an inhibitory effect on mercury oxidation reactions, because of the competitive formation of $\mathrm{SO}_{3}$ and $\mathrm{H}_{2} \mathrm{SO}_{4}$ (Cao et al., 2007; Ochiai et al., 2009). However, the equilibrium analysis showed that considering the average concentration of $\mathrm{SO}_{2}, \mathrm{O}_{2}$, and $\mathrm{Hg}$ in the analyzed flue gases, and particularly the high $\mathrm{SO}_{2}$ concentration in comparison to $\mathrm{Hg}$, this inhibitory effect can be neglected.

\section{- Influence of complex gas mixtures}

Bearing in mind that MSW incineration flue gas is composed of a mixture of different gases including $\mathrm{HCl}, \mathrm{O}_{2}, \mathrm{SO}_{2}$ and $\mathrm{NO}$, their impact on mercury speciation cannot be analyzed independently, and their co-influence needs also to be studied. For this purpose, the average gas composition of the described incineration plant, presented in Table 1, was considered.

The equilibrium calculation results showed that $\mathrm{SO}_{2}$ has a lower oxidizing capacity in comparison to $\mathrm{HCl}$. For instance, considering a $\mathrm{SO}_{2}$ concentration of $32.3 \mathrm{mg} / \mathrm{Nm}^{3}$, the $\mathrm{HgCl}_{2}$ content in flue gas increases with the $\mathrm{HCl}$ concentration, and is the dominant species above $0.05 \mathrm{mg} \mathrm{HCl} / \mathrm{Nm}^{3}$. This behavior suggests that under the usual conditions of MSW incineration processes, with high $\mathrm{HCl}$ concentrations in comparison to $\mathrm{Hg}$, and high $\mathrm{HCl}$ concentrations in comparison to $\mathrm{SO}_{2}$, the dominant oxidation reactions of elemental mercury are those with $\mathrm{HCl}$ (reaction (R2)).

Moreover, the impact of NO on mercury oxidation is very weak during gas cooling, and no remarkable differences in mercury speciation were observed with the change of NO concentration. In relation to this, some discrepancies have been reported regarding the influence of NO on the transformation of mercury species. Most of them are related to the composition of flue gases, depending if they come from coal combustion or MSW incineration processes. In the former case, considering the low chlorine content of coal, some authors have described a strong influence of NO, inhibiting or promoting homogeneous mercury oxidation reactions, depending on its amount in the flue gases (Niksa et al., 2001; Rumayor et al., 2018). In contrast, in the latter case, it has been reported that NO has a weak influence on mercury speciation, due to the presence of high $\mathrm{HCl}$ concentrations, whose mercury oxidation effect is dominant in the conditions of flue gas cooling devices (Zhou et al., 2013).

In this regard, from the performed parametric analysis concerning the flue gas composition, reactions (R2a) and (R2b) are proposed as the most suitable mechanism describing mercury transformation through the analyzed gas cooling tower. 


\subsection{Acid gases neutralization and mercury removal stage modeling}

As previously described, the analysis of mercury transformations and mercury removal in this process section was performed in two steps. At first, the influence of $\mathrm{NaHCO}_{3}$ on mercury speciation in the flue gas was analyzed using a thermochemical equilibrium approach. Then, the mechanisms related to mercury adsorption by activated lignite were studied considering the process kinetics.

\section{- Gas treatment with $\mathrm{NaHCO}_{3}$ - Influence on mercury speciation}

In general, the acid gases removal from the exhaust stream can be described by the neutralization reactions (R5)-(R7) (Antonioni et al., 2014).

$$
\begin{aligned}
& 2 \mathrm{NaHCO}_{3(s)} \rightarrow \mathrm{Na}_{2} \mathrm{CO}_{3(s)}+\mathrm{CO}_{2(\mathrm{~g})}+\mathrm{H}_{2} \mathrm{O}_{(\mathrm{g})} \\
& \mathrm{Na}_{2} \mathrm{CO}_{3(s)}+2 \mathbf{H C l}_{(\mathbf{g})} \rightarrow 2 \mathrm{NaCl}_{(s)}+\mathrm{CO}_{2(g)}+\mathrm{H}_{2} \mathrm{O}_{(\mathrm{g})} \\
& \mathrm{Na}_{2} \mathrm{CO}_{3(\mathrm{~s})}+\mathrm{SO}_{2(\mathrm{~g})}+1 / 2 \mathrm{O}_{2(\mathrm{~g})} \rightarrow \mathrm{Na}_{2} \mathrm{SO}_{4(s)}+\mathrm{CO}_{2(\mathrm{~g})}
\end{aligned}
$$

In consequence, the $\mathrm{NaHCO}_{3}$ injection to the process depends on the concentration of acid compounds in the gas, and particularly $\mathrm{HCl}$, which is the predominant one. The thermochemical calculations results showed that the amount of $\mathrm{NaHCO}_{3}$ fed to the process has a weak influence on the mercury speciation in the flue gas stream, and $\mathrm{HgCl}_{2}$ remains the main compound observed in this process stage. Nevertheless, it is worth noting that two trends were identified in relation to the $\mathrm{NaHCO}_{3}$ injection and $\mathrm{HCl}$ concentration in the flue gases. In particular, for molar ratios $\mathrm{NaHCO}_{3} / \mathrm{HCl}$ equal or below $1, \mathrm{HgCl}_{2}$ is the main mercury species in the gas and no changes are observed with the solid reactant amount increase. In contrast, in the case of an excess of $\mathrm{NaHCO}_{3}$, a fraction of $\mathrm{HgCl}_{2}$ may react with $\mathrm{Na}_{2} \mathrm{CO}_{3}$ to form $\mathrm{HgO}$ or $\mathrm{Hg}^{\circ}$ ((R8) and (R9)) (Ruzovic and Svoboda, 2019; Svoboda et al., 2016):

$\mathrm{Na}_{2} \mathrm{CO}_{3(s)}+\mathrm{HgCl}_{2(g)} \rightarrow 2 \mathrm{NaCl}_{(s)}+\mathrm{CO}_{2(g)}+\mathrm{HgO}_{(g)}$

$2 \mathrm{HgO}_{(g)} \rightarrow 2 \mathrm{Hg}_{(\mathrm{g})}^{\circ}+\mathrm{O}_{2(\mathrm{~g})}$

Considering that the typical temperature range for in-duct gas treatment process is between $150{ }^{\circ} \mathrm{C}$ and $300{ }^{\circ} \mathrm{C}$ (Verdone and De Filippis, 2004), it is worth noting that reactions (R8) and (R9) may be favored by an increase in the gas temperature. In particular, the equilibrium calculation results showed that for $\mathrm{NaHCO}_{3} / \mathrm{HCl}$ molar ratios higher than 1 , a gas temperature increase above $180{ }^{\circ} \mathrm{C}$ may result in the reduction of $\mathrm{HgCl}_{2}$ in $\mathrm{HgO}$ or $\mathrm{Hg}^{\circ}$, and in consequence, may be associated to higher mercury emissions to atmosphere.

For instance, about $2 \%$ of $\mathrm{HgCl}_{2}$ may be transformed to $\mathrm{Hg}^{\circ}$ and $\mathrm{HgO}$ at $190{ }^{\circ} \mathrm{C}$, the average temperature through the fabric filter, if a $\mathrm{NaHCO}_{3} / \mathrm{HCl}$ molar ratio above 1 is assumed. Even though this is not the case of the analyzed gas treatment unit, in the particular evaluated conditions (reported daily average operational parameters), the implications of this phenomena cannot be neglected, since depending on the gas flow and mercury concentration, it may result in an increase of the mercury emissions to the atmosphere. As already stated, the removal efficiency of mercury from flue gases is higher for oxidized compounds $\left(\mathrm{Hg}^{\mathrm{n}+}\right)$ in comparison to elemental mercury $\left(\mathrm{Hg}^{\circ}\right)$. In particular, different experimental reported works, have shown that the $\mathrm{HgCl}_{2}$ adsorption capacity of carbonaceous materials may be around 500 times higher in comparison to $\mathrm{Hg}^{\circ}$ (Ie et al., 2013; Karatza et al., 1996a).

\section{- Gas treatment with activated lignite - mercury adsorption}

Considering the simulation assumptions previously described, the impact of the process temperature, filtration time, and activated lignite injection rate on the mercury removal efficiency was analyzed. In agreement with the thermochemical equilibrium analysis results, it is assumed that all the mercury in the flue gas exists as mercury chloride $\left(\mathrm{HgCl}_{2}\right)$. Langmuir isotherm parameters for this compound, reported by Karatza et al. (1996), and summarized in Table 2 were used.

From the simulation results it can be observed that for the operating conditions of the bag filter, a decrease in the flue gas temperature promotes the $\mathrm{HgCl}_{2}$ adsorption by the activated lignite. For instance, in the presented case study, a temperature decrease from $200{ }^{\circ} \mathrm{C}$ to $180{ }^{\circ} \mathrm{C}$ may be related to a rise in the mercury removal efficiency between $7 \%$ and $10 \%$, as shown in Fig. 4a. Furthermore, it can be observed that removal efficiencies higher than $85 \%$ may be attained at $180^{\circ} \mathrm{C}$.

These results are in agreement with different reported works concluding that the adsorption capacity of several materials is inversely related to the process temperature. In the particular case of mercury capture, several authors suggested that the behavior of activated carbon and activated lignite is similar, and the mercury removal efficiency increases with the reduction of the temperature (Lin et al., 2006; Min et al., 2016). Nevertheless, it is important to point out that even if a decrease in the process temperature may promote the mercury capture by activated lignite, a too low temperature level may be detrimental for the acid gas abatement. In this case, temperatures around $200{ }^{\circ} \mathrm{C}$ are required to increase the reactivity of $\mathrm{NaHCO}_{3}$ and attain a better $\mathrm{HCl}$ and $\mathrm{SO}_{2}$ neutralization (Dal Pozzo et al., 2019). In accordance, process temperature for in-duct and baghouse filtration systems working with activated lignite and sodium bicarbonate should be chosen carefully, depending on the pollutants concentration in flue gases.

In addition to the temperature, the simulation results also showed that the activated lignite amount injected to the process has a significant impact on the mercury removal efficiency. From Fig. 4b, it can be observed that at $190{ }^{\circ} \mathrm{C}$, a variation in the acti-
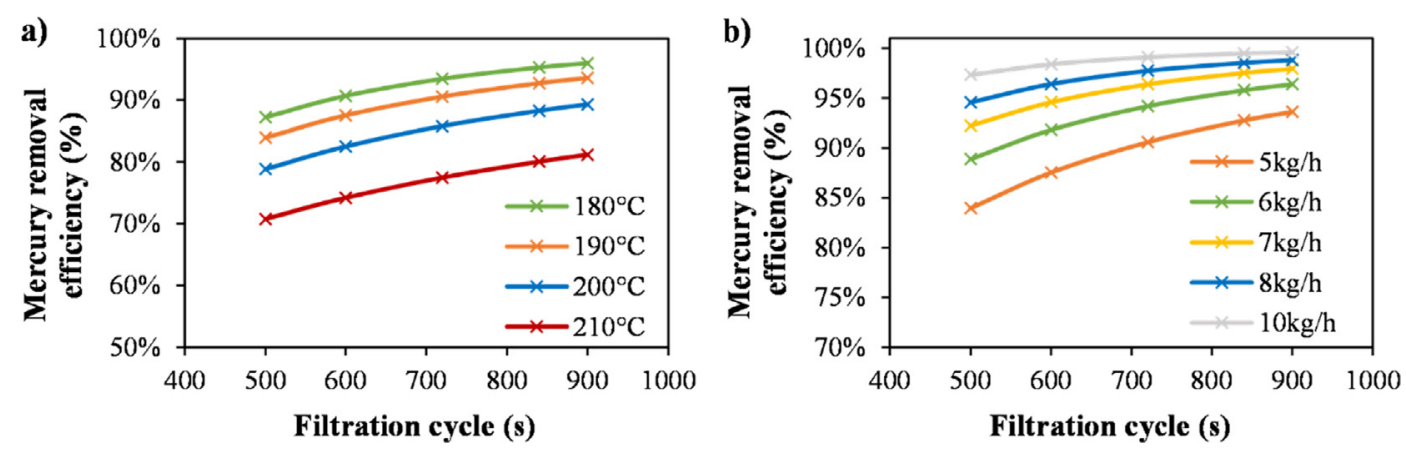

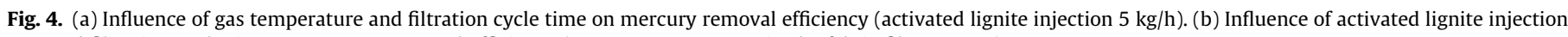
rate and filtration cycle time on mercury removal efficiency (average temperature in the fabric filter $190^{\circ} \mathrm{C}$ ). 
vated lignite mass flow rate from $5 \mathrm{~kg} / \mathrm{h}$ to $7 \mathrm{~kg} / \mathrm{h}$ is followed by an increase on the mercury removal efficiency from $5 \%$ to $10 \%$. Likewise, for the analyzed process conditions, the simulation results showed that mercury removal efficiencies higher that 95\% can be obtained with activated lignite injection rates above $8 \mathrm{~kg} / \mathrm{h}$. These results are also in accordance with several reported studies, which showed that the adsorbent amount available for mercury capture is directly correlated to the mercury removal efficiency in both laboratory-scale and industrial-scale facilities (Ghorishi and Gullett, 1998; Li et al., 2018; Scala, 2001b). In fact, higher adsorbent concentrations in the flue gases are associated to a greater collision probability between the solid reactant and the pollutant, and also a greater surface area available for adsorption. In accordance, higher activated lignite injection rates result in better mercury adsorption efficiencies.

Moreover, it can be noticed from Fig. $4 a$ and $b$ that the increase in the gas filtration time through the baghouse is also associated to higher mercury removal percentages. Indeed, longer filtration cycles result in a greater amount of solid reactant available in the filter for the pollutant adsorption process, improving the overall removal efficiency.

The simulation results also showed that an increase on the mercury concentration in the flue gas may have a negative effect on the mercury removal efficiency. This impact is nevertheless not significant $(<1 \%)$ if the daily average variations of the mercury concentration at the inlet of the treatment unit are considered $(\mathrm{Hg}$ tot $=98 \pm 50 \mu \mathrm{g} / \mathrm{Nm}^{3}$ ). However, it is worth mentioning that depending on the nature of the incinerated wastes and their mercury content, some mercury peaks as high as $800-1000 \mu \mathrm{g} / \mathrm{Nm}^{3}$ may be observed at the inlet of the unit during short periods of time. In relation to this, the simulation results showed that at $180{ }^{\circ} \mathrm{C}$ an increase on the mercury concentration from 98 to $1000 \mu \mathrm{g} / \mathrm{Nm}^{3}$ in the treated gas results in a $0.5 \%$ reduction of the pollutant uptake (activated lignite injection rate of $5 \mathrm{~kg} / \mathrm{h}$ and average filtration cycle time of $600 \mathrm{~s}$ ). This negative effect may be stronger at higher temperatures, with a decrease near $4 \%$ on the mercury removal efficiency at $210{ }^{\circ} \mathrm{C}$.

Accordingly, an empirical correlation to predict the mercury removal efficiency from the main operating parameters of the flue gas treatment line can be proposed from the simulation results, considering the impact of the activated lignite mass flow rate $(m)$, the average temperature through the fabric filter $(T)$, and the filtration cycle time ( $t$ ) (Eq. (3)):

$$
\begin{aligned}
\operatorname{MRE}(\%)= & {[[(-0.00025 t+0.27625) \ln (m)+(0.00061 t+0.34145)]} \\
& \left.-\left[0.00013 T^{2}-0.04573 T+4.0194\right]\right] \times 100
\end{aligned}
$$

With $\mathrm{m}$ in $\mathrm{kg} / \mathrm{h}, T$ in ${ }^{\circ} \mathrm{C}$ and $t$ in seconds. Since the flue gas treatment process analysis in this work is based on daily average values, the occasional peaks on mercury concentration are not considered in the proposed correlation. The presented expression is applicable in the temperature and filtration cycle ranges between $180^{\circ} \mathrm{C}$ and $210{ }^{\circ} \mathrm{C}$, and $500 \mathrm{~s}$ to $900 \mathrm{~s}$ respectively, taking into account that these are the typical operating conditions of full-scale units working with $\mathrm{NaHCO}_{3}$ and activated lignite, as previously stated. The validity of this expression to predict the mercury removal efficiency of the analyzed full-scale flues gas treatment unit is discussed in Section 3.4.

\subsection{Selective catalytic reduction (SCR) stage modeling}

The flue gas composition measured at the exit of the bag filter (EF) was considered for the modeling of this process stage. At this point, small concentrations of $\mathrm{HCl}, \mathrm{SO}_{2}$, and mercury compounds are still present in the flue gas. However, it is possible to observe that $\mathrm{HCl}$ concentration is significantly higher in comparison to $\mathrm{Hg}$ concentration $\left(5.7 \mathrm{mg} / \mathrm{Nm}^{3} \mathrm{HCl}\right.$ in comparison to $10.5 \mu \mathrm{g} /$ $\mathrm{Nm}^{3} \mathrm{Hg}$ tot). Thus, in agreement with the simulation results presented in the previous section, it is assumed that $\mathrm{HgCl}_{2}$ is the main mercury species in the gas at the inlet of the SCR unit.

The thermochemical equilibrium calculations showed that for the average operating conditions of the SCR unit, the $\mathrm{NH}_{3}$ injection in the flue gas stream does not have a visible reduction effect on the gaseous $\mathrm{HgCl}_{2}$, and then, no variations were noticed in the mercury speciation. The same behavior was observed with the increase of the injected $\mathrm{NH}_{3}$ amount above the stoichiometric molar ratio $\mathrm{NH}_{3}$ /NO. Even if the thermochemical equilibrium approach is not suitable to analyze the reactions taking place at the surface of the catalyzer, it is worth noting that several studies have shown that a certain amount of mercury may be adsorbed by the SCR unit, competing with $\mathrm{NH}_{3}$ and $\mathrm{HCl}$ (Eswaran and Stenger, 2005; Presto and Granite, 2006). This phenomena might be associated to a sudden desorption of mercury when the concentration of $\mathrm{NH}_{3}$ or $\mathrm{HCl}$ increases, along with a mercury peak at the chimney exit (Presto and Granite, 2006; Reissner et al., 2015). Nevertheless, this event was not identified in the analyzed gas treatment unit, and no particular variations in mercury speciation were observed through the SCR reactor.

\subsection{Comparison between process modeling and full-scale parametric analysis results}

In relation to the mercury speciation, the thermochemical equilibrium simulation results are in agreement with the flue gas composition measured at the three selected points of the treatment line. In particular, it was noticed that under the described average process conditions and as observed in Table 1, mercury is mainly present in the flue gas in an oxidized form $\left(\mathrm{Hg}^{\mathrm{n}+}\right)$, most likely $\mathrm{HgCl}_{2}$, considering the relatively high $\mathrm{HCl}$ content in the gas stream in comparison to $\mathrm{Hg}$. From the measured gas composition and speciation, it was possible to observe that at the inlet of the spray tower (ST), almost $90 \%$ of the total mercury correspond to oxidized compounds $\left(\mathrm{Hg}^{\mathrm{n}+}\right)$. Similarly, this value is near 95\% at the exit of the fabric filter (EF) and the chimney $(\mathrm{CH})$. The differences with the simulation results, suggesting that almost all the mercury is found in oxidized form ( $>99 \%$ ), are certainly related to the fact that the full-scale process is not at perfect equilibrium, and then, the complete oxidation of mercury is not attained during the flue gas residence time in the process compartments.

Furthermore, in relation to the mercury removal efficiency, the simulation results showed that an increase in the process performance can be achieved by the use of different strategies. For the typical composition of MSW incineration flue gases (i.e. $[\mathrm{HCl}] \gg$ $[\mathrm{Hg}]$ and $\left.[\mathrm{HCl}] \gg\left[\mathrm{SO}_{2}\right]\right)$, it was observed that the reduction of the mercury emissions to the atmosphere is related to lower process temperatures, higher activated lignite injection rates, or longer filtration cycle times. This is in agreement with the results of the parametric analysis performed in the full-scale unit and summarized in Table 4.

In particular, it was observed that a flue gas temperature decrease of $10{ }^{\circ} \mathrm{C}$ (from $205^{\circ} \mathrm{C}$ to $195{ }^{\circ} \mathrm{C}$ ) at the exit of the cooling tower (activated lignite injection rate of $5 \mathrm{~kg} / \mathrm{h}$ and average filtration cycle time of $600 \mathrm{~s}$ ), resulted in a rise on the measured plant mercury removal efficiency around $5 \%$, close to the calculated values $(\sim 6 \%)$. As previously described, this trend may be associated to an increase in the oxidized mercury content in the flue gas, and the enhancement of the mercury adsorption capacity by activated lignite, promoted by a temperature reduction. 
Table 4

Mercury removal efficiency measured during the full-scale parametric analysis and comparison to calculated values.

\begin{tabular}{|c|c|c|c|}
\hline & Operating parameters & Measured MRE & Calculated MRE (\%) \\
\hline Baseline conditions & $\begin{array}{l}\text { Temperature - exit cooling tower: } 205^{\circ} \mathrm{C} \\
\text { Activated lignite injection rate: } 5 \mathrm{~kg} / \mathrm{h} \\
\text { Filtration cycle time: } 600 \mathrm{~s}(12 \mathrm{mbar})\end{array}$ & $86.4 \pm 2.5 \%$ & $83.7 \%$ \\
\hline Parametric test 1 & $\begin{array}{l}\text { Temperature - exit cooling tower: } 195^{\circ} \mathrm{C} \text { Activated lignite injection rate: } 5 \mathrm{~kg} / \mathrm{h} \\
\text { Filtration cycle time: } 600 \mathrm{~s}(12 \mathrm{mbar})\end{array}$ & $91.2 \pm 0.5 \%$ & $88.6 \%$ \\
\hline Parametric test 2 & $\begin{array}{l}\text { Temperature - exit cooling tower: } 195^{\circ} \mathrm{C} \text { Activated lignite injection rate: } 10 \mathrm{~kg} / \mathrm{h} \\
\text { Filtration cycle time: } 600 \mathrm{~s}(12 \mathrm{mbar})\end{array}$ & $95.5 \pm 0.5 \%$ & $97.2 \%$ \\
\hline Parametric test 3 & $\begin{array}{l}\text { Temperature - exit cooling tower: } 195^{\circ} \mathrm{C} \text { Activated lignite injection rate: } 5 \mathrm{~kg} / \mathrm{h} \\
\text { Filtration cycle time: } 900 \mathrm{~s} \text { ( } 14 \mathrm{mbar})\end{array}$ & $93.2 \pm 0.3 \%$ & $94.8 \%$ \\
\hline
\end{tabular}

Likewise, it was noticed that a rise on the activated lignite injection rate from $5 \mathrm{~kg} / \mathrm{h}$ to $10 \mathrm{~kg} / \mathrm{h}(0.5-1 \mathrm{~kg} /$ ton waste) resulted also in an average increase of mercury removal efficiency of near $5 \%$ $\left(195{ }^{\circ} \mathrm{C}\right.$ at the exit of the cooling tower and average filtration cycle time of $600 \mathrm{~s}$ ), compared to the calculated value from the simulation results $(\sim 9 \%)$. A similar observation was made regarding the filtration cycle time in the baghouse filter (also controlled by the pressure drop through the filter). In particular, an increase from $600 \mathrm{~s}$ to $900 \mathrm{~s}$ (pressure drop from 12 mbar to $14 \mathrm{mbar}$ ) was followed by an improvement of the mercury removal efficiency near $3 \%\left(195{ }^{\circ} \mathrm{C}\right.$ at the exit of the cooling tower and activated lignite injection rate of $5 \mathrm{~kg} / \mathrm{h}$ ), compared to a calculated value of $7 \%$. The differences between the simulation results and the measured values are probably related to the simplifications adopted for the modeling process. In particular, the activated lignite and $\mathrm{NaHCO}_{3}$ deposition on the filter surface is not homogeneous in real operation devices, resulting in reduced mercury removal performance. Moreover, non-uniformities in the gas flow may also occur during the filter cleaning cycles. Nevertheless, the observed trends show that despite these slight differences, the proposed modeling approach is suitable for the description of the analyzed process.

Considering that full-scale parametric analysis are not often possible due to the high operational costs of incineration facilities, this study confirmed the suitability of the presented process simulation strategy to evaluate the behavior of industrial flue gas treatment units, and determine the operation parameters that may have the greatest impact on the mercury removal efficiency of the process. In the same way, the proposed empirical expression to predict the mercury removal efficiency from the knowledge of the fabric filter main operating parameters can be a useful tool for full-scale facilities equipped with dry flue gas treatment units working with $\mathrm{NaHCO}_{3}$ and lignite coke.

\section{Conclusion}

The process simulation and parametric study performed in a dry full-scale flue gas treatment unit showed that an improvement on the mercury removal efficiency can be attained by properly adjusting different process parameters like temperature, adsorbent injection rate, or filtration cycle time. Considering the typical flue gas composition of municipal solid waste incineration facilities, a decrease in the process temperature results in better mercury removal efficiencies, associated to a higher oxidation extent of elemental mercury on $\mathrm{HgCl}_{2}$, and an enhanced adsorbent capacity. Moreover, a reduction of mercury emissions may be attained by increasing the adsorbent injection rate to the process, or the filtration cycle time through the fabric filter.

Considering that full-scale parametric analysis are not often possible due to the high operational costs of incineration facilities, this study confirmed the suitability of the proposed process simulation strategy to evaluate the behavior of industrial flue gas treatment units, and determine the operation parameters that may have the greatest impact on the mercury removal efficiency of the process. An empirical correlation to predict the mercury removal efficiency from the main treatment line operating parameters was proposed, representing a useful tool for full-scale facilities equipped with dry flue gas treatment units using $\mathrm{NaHCO}_{3}$ and lignite coke.

The approach developed in this work, combining thermodynamics and kinetics modeling at full scale to understand the mercury transformation mechanisms in the flue gas seems to the best of our knowledge, to be a significant contribution to the state-ofthe-art.

\section{Declaration of Competing Interest}

The authors declare that they have no known competing financial interests or personal relationships that could have appeared to influence the work reported in this paper.

\section{Acknowledgments}

The authors would like to thank ADEME (French agency for Energy and Environmental Protection), for the financial support accorded for the development of MIMOSA project (Fate of mercury in incineration: Metrology, Speciation and Impact of the Effectiveness of Abatement), under the grant 1706C0006.

\section{References}

Abanades, S., Flamant, G., Gagnepain, B., Gauthier, D., 2002. Fate of heavy metals during municipal solid waste incineration. Waste Manage. Res. 20, 55-68. https://doi.org/10.1016/j.jhazmat.2007.12.025.

Ahmad, T., Park, J., Keel, S., Yun, J., Lee, U., Kim, Y., Lee, S.S., 2018. Behavior of heavy metals in air pollution control devices of $2,400 \mathrm{~kg} / \mathrm{h}$ municipal solid waste incinerator. Korean J. Chem. Eng. 35, 1823-1828. https://doi.org/10.1007/ s11814-018-0101-1.

Antonioni, G., Guglielmi, D., Cozzani, V., Stramigioli, C., Corrente, D., 2014. Modelling and simulation of an existing MSWI flue gas two-stage dry treatment. Process Saf. Environ. Prot. 92, 242-250. https://doi.org/10.1016/j. psep.2013.02.005

Bale, C.W., Bélisle, E., Chartrand, P., Decterov, S.A., Eriksson, G., Gheribi, A.E., Hack, K., Jung, I.H., Kang, Y.B., Melançon, J., Pelton, A.D., Petersen, S., Robelin, C., Sangster, J., Spencer, P., Van Ende, M.A., 2016. Reprint of: FactSage thermochemical software and databases, 2010-2016. Calphad Comput. Coupling Phase Diagrams Thermochem. 55, 1-19. https://doi.org/10.1016/ j.calphad.2016.07.004.

Beylot, A., Muller, S., Descat, M., Ménard, Y., Villeneuve, J., 2018. Life cycle assessment of the French municipal solid waste incineration sector. Waste Manage. 80, 144-153. https://doi.org/10.1016/j.wasman.2018.08.037.

Cao, Y., Chen, B., Wu, J., Cui, H., Smith, J., Chen, C.K., Chu, P., Pan, W.P., 2007. Study of mercury oxidation by a selective catalytic reduction catalyst in a pilot-scale slipstream reactor at a utility boiler burning bituminous coal. Energy Fuels 21 145-156. https://doi.org/10.1021/ef0602426.

Carey, T.R., Hargrove, O.W., Carl, J., Richardson, F.F., Chang, Frank, R., Meserole, B.B. 1998. Factors affecting mercury control in utility flue gas using activated carbon. J. Air Waste Manage. Assoc. 48, 1166-1174. https://doi.org/10.1080/ 10473289.1998 .10463753$.

Chen, Y.-S., Hsiau, S.-S., 2009. Cake formation and growth in cake filtration. Powder Technol. 192, 217-224. https://doi.org/10.1016/j.powtec.2008.12.014. 
Cheng, X., Bi, X.T., 2014. A review of recent advances in selective catalytic NO reduction reactor technologies. Particuology 16, 1-18. https://doi.org/10.1016/ j.partic.2014.01.006.

Dal Pozzo, A., Moricone, R., Tugnoli, A., Cozzani, V., 2019. Experimental investigation of the reactivity of sodium bicarbonate toward hydrogen chloride and sulfur dioxide at low temperatures. I\&EC 58, 6316-6324. https://doi.org/10.1021/acs. iecr.9b00610.

Eswaran, S., Stenger, H.G., 2005. Understanding Mercury Conversion in Selective Catalytic Reduction (SCR) Catalysts. Energy Fuels 19, 2328-2334. https://doi. org/10.1021/ef050087f

European Commission, 2019. Commission implementing decision (EU) 2019/2010 of November 2019 establising the BAT conclusions, under Directive 2010/75/EU of the European Parliament and of the Council, for waste incineration. Off. J. Eur. Union 62, 55-92.

Feeley, T.J., Jones, A.P., Brickett, L.A., O’Palko, B.A., Miller, C.E., Murphy, J.T., 2009. An update on DOE's Phase II and Phase III mercury control technology R\&D program. Fuel Process. Technol. 90, 1388-1391. https://doi.org/10.1016 j.fuproc.2009.05.012.

Garrick, S.C., Bühlmann, M., 2018. Modeling of Gas-to-Particle Mass Transfer in Turbulent Flows. Springer.

Gharebaghi, M., Hughes, K.J., Porter, R.T.J., Pourkashanian, M., Williams, A., 2011 Mercury speciation in air-coal and oxy-coal combustion: A modelling approach. Proc. Combust. Inst. 33, 1779-1786. https://doi.org/10.1016/J. PROCI.2010.07.068

Ghorishi, B., Gullett, B.K., 1998. Sorption of mercury species by activated carbons and calcium-based sorbents: effect of temperature, mercury concentration and acid gases. Waste Manage. Res. 16, 582-593.

Ha, E., Basu, N., Bose-O’Reilly, S., Dórea, J.G., McSorley, E., Sakamoto, M., Chan, H.M. 2017. Current progress on understanding the impact of mercury on human health. Environ. Res. 152, 419-433. https://doi.org/10.1016/j. envres.2016.06.042.

Hall, B., Lindqvist, O., Ljungström, E., 1990. Mercury chemistry in simulated flue gases related to waste incineration conditions. Environ. Sci. Technol. 24, 108111. https://doi.org/10.1021/es00071a013.

Hall, B., Schager, P., Lindqvist, O., 1991. Chemical reactions of mercury in combustion flue gases. Water, Air, Soil Pollut. 56, 3-14. https://oi.org/ 10.1007/BF00342256.

Hassett, D.J., Eylands, K.E., 1999. Mercury capture on coal combustion fly ash. Fuel 78, 243-248. https://doi.org/10.1016/S0016-2361(98)00150-1.

Hranisavljevic, J., Fontijn, A., 1997a. Kinetics of ground-state $\mathrm{Cd}$ reactions with $\mathrm{Cl} 2$ $\mathrm{O} 2$, and $\mathrm{HCl}$ over wide temperature ranges. J. Phys. Chem. A 101, 2323-2326. https://doi.org/10.1021/jp963074z.

Hranisavljevic, J., Fontijn, A., 1997b. Kinetics of ground-state Cd reactions with $\mathrm{Cl} 2$ O2, and $\mathrm{HCl}$ over wide temperature ranges. J. Phys. Chem. A 101, 2323-2326.

Ie, I.-R., Hung, C.-H., Jen, Y.-S., Yuan, C.-S., Chen, W.-H., 2013. Adsorption of vaporphase elemental mercury $(\mathrm{Hg} 0)$ and mercury chloride $(\mathrm{HgCl} 2)$ with innovative composite activated carbons impregnated with $\mathrm{Na} 2 \mathrm{~S}$ and $\mathrm{SO}$ in differen sequences. Chem. Eng. J. 229, 469-476. https://doi.org/10.1016/j. cej.2013.06.059.

Jannelli, E., Minutillo, M., 2006. Simulation of the flue gas cleaning system of an RDF incineration power plant. Waste Manage. 27, 684-690. https://doi.org/10.1016 j.wasman.2006.03.017.

Karatza, D., Lancia, A., Musmarra, D., 1998. Fly ash capture of mercuric chloride vapors from exhaust combustion gas. Environ. Sci. Technol. 32, 3999-4004. https://doi.org/10.1021/es971074m.

Karatza, Despina, Lancia, A., Musmarra, D., Pepe, F., 1996a. Adsorption of metallic mercury on activated carbon. Symp. Combust. 26, 2439-2445. https://doi.org 10.1016/S0082-0784(96)80074-9.

Karatza, Despina, Lancia, A., Musmarra, D., Pepe, F., Volpicelli, G., 1996b. Removal of mercuric chloride from flue gas by sulfur impregnated activated carbon Hazard. Waste Hazard. Mater. 13, 95-105. https://doi.org/10.1089/ hwm.1996.13.95.

Karatza, D., Lancia, A., Musmarra, D., Pepe, F., Volpicelli, G., 1996. Kinetics of adsorption of mercuric chloride vapors on sulfur impregnated activated carbon. Combust. Sci. Technol. 112, 163-174. https://doi.org/10.1080/ 00102209608951954.

Li, G., Wu, Q., Wang, S., Duan, Z., Su, H., Zhang, L., Li, Z., Tang, Y., Zhao, M., Chen, L. Liu, K., Zhang, Y., 2018. Improving flue gas mercury removal in waste incinerators by optimization of carbon injection rate. Environ. Sci. Technol. 52, 1940-1945. https://doi.org/10.1021/acs.est.7b05560.

Lighty, J.S., Silcox, G., Senior, C.L., Helble, J.J., 2008. Fundamentals of Mercury Oxidation in Flue Gas. University of Utah - DOE Project Final Report, Salt Lake City.

Lin, H.-Y., Yuan, C.-S., Chen, W.-C., Hung, C.-H., 2006. Determination of the adsorptive capacity and adsorption isotherm of vapor-phase mercury chloride on powdered activated carbon using thermogravimetric analysis. J. Air Waste Manage. Assoc. 56, 1550-1557. https://doi.org/10.1080/ 10473289.2006.10464561.

Min, H., Ahmad, T., Lee, S.-S., 2016. Mercury adsorption characteristics as dependent upon the physical properties of activated carbon. Energy Fuels 31, 724-729. https://doi.org/10.1021/acs.energyfuels.6b02246.
Nichita, D.V., Gomez, S., Luna, E., 2002. Multiphase equilibria calculation by direct minimization of Gibbs free energy with a global optimization method. Comput. Chem. Eng. 26, 1703-1724.

Niksa, S., Helble, J.J., Fujiwara, N., 2001. Kinetic modeling of homogeneous mercury/ oxidation: The importance of $\mathrm{NO}$ and $\mathrm{H} 2 \mathrm{O}$ in predicting oxidation in coalderived systems. Environ. Sci. Technol. 35, 3701-3706. https://doi.org/10.1021/ es010728v.

Ochiai, R., Uddin, M.A., Sasaoka, E., Wu, S., 2009. Effects of $\mathrm{HCl}$ and $\mathrm{SO} 2$ concentration on mercury removal by activated carbon sorbents in coalderived flue gas. Energy Fuels 23, 4734-4739. https://doi.org/10.1021/ ef900057e.

Pavlish, J.H., Sondreal, E.A., Mann, M.D., Olson, E.S., Galbreath, K.C., Laudal, D.L., Benson, S.A., 2003. Status review of mercury control options for coal-fired power plants. Fuel Process. Technol. 82, 89-165. https://doi.org/10.1016/ S0378-3820(03)00059-6.

Presto, A.A., Granite, E.J., 2006. Critical review survey of catalysts for oxidation of mercury in flue gas. Environ. Sci. Technol. 40, 5601-5609. https://doi.org/ 10.1021/es060504i.

Quina, M.J., Bordado, J.C., Quinta-Ferreira, R.M., 2008. Treatment and use of air pollution control residues from MSW incineration: An overview. Waste Manage. https://doi.org/10.1016/j.wasman.2007.08.030.

Reissner, H., Crèvecoeur, S., Kramer, M., Kraus, N., Kuivalainen, R., Michel, M., Oberheid, F., Bernd, V., 2015. Mercury Removal - Guideline for Assessment and Design Recommendations - European Power. Plant Suppliers Association.

Rumayor, M., Svoboda, K., Švehla, J., Pohořelý, M., Šyc, M., 2018. Mitigation of gaseous mercury emissions from waste-to-energy facilities: Homogeneous and heterogeneous $\mathrm{Hg}$-oxidation pathways in presence of fly ashes. J. Environ. Manage. 206, 276-283. https://doi.org/10.1016/j.jenvman.2017.10.039.

Ruthven, D., 1984. Principles of Adsorption and Adsorption Processes. John Wiley \& Sons.

Ruzovic, T., Svoboda, K., 2019. Thermodynamic possibilities of fue gas dry desulfurization, de-HCl. Chem. Pap. 74, 951-962.

Scala, F., 2001a. Simulation of mercury capture by activated carbon injection in incinerator flue gas. 1 In-duct removal. Environ. Sci. Technol. 35, 4367-4372. https://doi.org/10.1021/es010065h.

Scala, F., 2001b. Simulation of mercury capture by activated carbon injection in incinerator flue gas. 2 Fabric filter removal. Environ. Sci. Technol. 35, 43734378. https://doi.org/10.1021/es010066.

Senior, C.L., Sarofim, A.F., Zeng, T., Helble, J.J., Mamani-Paco, R., 2000. Gas-phase transformations of mercury in coal-fired power plants. Fuel Process. Technol. 63, 197-213. https://doi.org/10.1016/S0378-3820(99)00097-1.

Shabbar, S., Janajreh, I., 2012. Thermodynamic equilibrium analysis of coal gasification using Gibbs energy minimization method. Energy Convers. Manage. 65, 755-763. https://doi.org/10.1016/jenconman.2012.02.032.

Skodras, G., Diamantopoulou, I., Pantoleontos, G., Sakellaropoulos, G.P., 2008. Kinetic studies of elemental mercury adsorption in activated carbon fixed bed reactor. J. Hazard. Mater. 158, 1-13. https://doi.org/10.1016/j. jhazmat.2008.01.073.

Sliger, R.N., Kramlich, J.C., Marinov, N.M., 2000. Towards the development of a chemical kinetic model for the homogeneous oxidation of mercury by chlorine species. Fuel Process. Technol. 65, 423-438. https://doi.org/10.1016/S03783820(99)00108-3.

Srivastava, R.K., Jozewicz, W., Srivastava, J., 2001. Flue gas desulfurization: the state of the art. J. Air Waste Manage. Assoc. 51, 1676-1688. https://doi.org/10.1080/ 10473289.2001.10464387.

Svoboda, K., Hartman, M., Šyc, M., Pohořelý, M., Kameníková, P., Jeremiáš, M., Durda, T., 2016. Possibilities of mercury removal in the dry flue gas cleaning lines of solid waste incineration units. J. Environ. Manage. 166, 499-511. https://doi. org/10.1016/j.jenvman.2015.11.001.

Tao, Z., Dai, S., Chai, X., 2017. Mercury emission to the atmosphere from municipal solid waste landfills: A brief review. Environ. Atmos. https://doi.org/10.1016/j. atmosenv.2017.09.046.

Verdone, N., De Filippis, P., 2004. Thermodynamic behaviour of sodium and calcium based sorbents in the emission control of waste incinerators. Chemosphere 54 975-985. https://doi.org/10.1016/j.chemosphere.2003.09.041.

Wang, Y., Duan, Y., Yang, L., Jiang, Y., Wu, C., Wang, Q., Yang, X., 2008. Comparison of mercury removal characteristic between fabric filter and electrostatic precipitators of coal-fired power plants. J. Fuel Chem. Technol. 36, 23-29. https://doi.org/10.1016/S1872-5813(08)60009-2.

Xu, M., Qiao, Y., Zheng, C., Li, L., Liu, J., 2003. Modeling of homogeneous mercury speciation using detailed chemical kinetics. Combust. Flame 132, 208-218. https://doi.org/10.1016/S0010-2180(02)00438-8.

Zhou, J., Zhongyang, L., Yanqun, Z., Mengxiang, F., 2013. Mercury Emission and its Control in Chinese Coal-Fired Power Plants, Advanced Topics in Science and Technology in China. Springer. https://doi.org/10.1007/978-3-642-37874-4

Zhou, Q., Duan, Y.-F., Zhao, S.-L., Zhu, C., She, M., Zhang, J., Wang, S.-Q., 2015. Modeling and experimental studies of in-duct mercury capture by activated carbon injection in an entrained flow reactor. Fuel Process. Technol. 140, $304-$ 311. https://doi.org/10.1016/j.fuproc.2015.08.018. 